\title{
Oxidative stress response in regulatory and conventional T cells: a comparison between patients with chronic coronary syndrome and healthy subjects
}

\author{
Anna K. Lundberg ${ }^{1}$, Rosanna W. S. Chung ${ }^{1}$, Louise Zeijlon ${ }^{1}$, Gustav Fernström ${ }^{1}$ and Lena Jonasson ${ }^{2,3^{*}}$ (1)
}

\begin{abstract}
Background: Inflammation and oxidative stress form a vicious circle in atherosclerosis. Oxidative stress can have detrimental effects on T cells. A unique subset of $\mathrm{CD}^{+}{ }^{+} T$ cells, known as regulatory $T\left(T_{\text {reg }}\right)$ cells, has been associated with atheroprotective effects. Reduced numbers of $\mathrm{T}_{\text {reg }}$ cells is a consistent finding in patients with chronic coronary syndrome (CCS). However, it is unclear to what extent these cells are sensitive to oxidative stress. In this pilot study, we tested the hypothesis that oxidative stress might be a potential contributor to the $T_{\text {reg }}$ cell deficit in CCS patients.

Methods: Thirty patients with CCS and 24 healthy controls were included. $T_{\text {reg }}\left(C D 4^{+} \mathrm{CD} 25^{+} \mathrm{CD} 127^{-}\right)$and conventional $\mathrm{T}\left(\mathrm{CD}^{+}{ }^{+} \mathrm{CD}_{25} 5^{-}, \mathrm{T}_{\text {conv }}\right)$ cells were isolated and treated with increasing doses of $\mathrm{H}_{2} \mathrm{O}_{2}$. Intracellular ROS levels and cell death were measured after 2 and $18 \mathrm{~h}$, respectively. The expression of antioxidant genes was measured in freshly isolated $\mathrm{T}_{\text {reg }}$ and $\mathrm{T}_{\text {conv }}$ cells. Also, total antioxidant capacity (TAC) was measured in fresh peripheral blood mononuclear cells, and oxidized (ox) LDL/LDL ratios were determined in plasma.

Results: At all doses of $\mathrm{H}_{2} \mathrm{O}_{2}, \mathrm{~T}_{\text {reg }}$ cells accumulated more $\mathrm{ROS}$ and exhibited higher rates of death than their $\mathrm{T}_{\text {conv }}$ counterparts, $p<0.0001 . T_{\text {reg }}$ cells also expressed higher levels of antioxidant genes, including thioredoxin and thioredoxin reductase-1 $(p<0.0001)$, though without any differences between CCS patients and controls. $T_{\text {conv }}$ cells from CCS patients were, on the other hand, more sensitive to oxidative stress ex vivo and expressed more thioredoxin reductase- 1 than $T_{\text {conv }}$ cells from controls, $p<0.05$. Also, TAC levels were lower in patients, $0.97 \mathrm{vs} 1.53 \mathrm{UAE} / 100 \mu \mathrm{g}$, $p=0.001$, while oxLDL/LDL ratios were higher, 29 vs $22, p=0.006$.
\end{abstract}

Conclusion: $T_{\text {reg }}$ cells isolated from either CCS patients or healthy controls were all highly sensitive to oxidative stress ex vivo. There were signs of oxidant-antioxidant imbalance in CCS patients and we thus assume that oxidative stress may play a role in the reduction of $\mathrm{T}_{\text {reg }}$ cells in vivo.

Keywords: Coronary artery disease, Chronic coronary syndrome, T cell, Regulatory T cell, Oxidative stress

*Correspondence: lena.jonasson@liu.se

${ }^{3}$ Department of Cardiology, Linköping University Hospital, 581 85 Linköping, Sweden

Full list of author information is available at the end of the article

\section{Background}

Oxidative stress and chronic inflammation are closely linked phenomena that can perpetuate each other and easily form a vicious circle in chronic disease. The simultaneous existence of oxidative stress and low-grade inflammation in atherosclerosis is well established. Oxidative stress, defined as chronic overproduction of

c) The Author(s) 2021. This article is licensed under a Creative Commons Attribution 4.0 International License, which permits use, sharing, adaptation, distribution and reproduction in any medium or format, as long as you give appropriate credit to the original author(s) and the source, provide a link to the Creative Commons licence, and indicate if changes were made. The images or other third party material in this article are included in the article's Creative Commons licence, unless indicated otherwise in a credit line to the material. If material is not included in the article's Creative Commons licence and your intended use is not permitted by statutory regulation or exceeds the permitted use, you will need to obtain permission directly from the copyright holder. To view a copy of this licence, visit http://creativeco mmons.org/licenses/by/4.0/. The Creative Commons Public Domain Dedication waiver (http://creativecommons.org/publicdomain/ zero/1.0/) applies to the data made available in this article, unless otherwise stated in a credit line to the data. 
reactive oxygen species (ROS) or rather an imbalance between oxidants and antioxidants in favor of the oxidants [1], plays a major role in the development of atherosclerosis [2, 3]. In humans, a variety of circulating markers of oxidative stress, including oxidative modification of low density lipoprotein (LDL), have shown associations with cardiovascular disease $[4,5]$. It has also been shown that oxidized (ox) LDL can elicit a robust immune response in atherosclerosis, involving activation of $\mathrm{CD} 4^{+}$ $\mathrm{T}$ cells [6].

Although moderate levels of ROS are necessary for the proper regulation of $\mathrm{T}$ cell activation, large quantities of ROS may have detrimental effects on T cells, such as decreased viability [7]. This may be an area of special interest in understanding the $\mathrm{T}$ cell perturbations associated with coronary artery disease. The systemic $\mathrm{T}$ cell activation that occurs in many patients with acute coronary syndrome (ACS) does not normalize over time but becomes persistent, despite clinical stability and medical treatment [8-10].

The perturbed $\mathrm{T}$ cell repertoire in patients with coronary artery disease is also associated with a decrease of regulatory $\mathrm{T}\left(\mathrm{T}_{\text {reg }}\right)$ cells, a specialized subpopulation of $\mathrm{CD} 4{ }^{+} \mathrm{CD} 25^{+} \mathrm{T}$ cells. These cells were first identified in 1995 by Sakaguchi et al. [11] as a subset of thymusderived $\mathrm{CD} 4^{+} \mathrm{T}$ cells that expressed high levels of the interleukin (IL-2) receptor $\alpha$-chain CD25 and protected thymectomized mice from autoimmunity. In humans, several autoimmune and inflammatory pathologies have been associated with numerical deficits in $T_{\text {reg }}$ cells as well as increased apoptosis of $\mathrm{T}_{\text {reg }}$ cells [12-14]. Interestingly, $\mathrm{T}_{\text {reg }}$ cell deficits have also been reported in patients with ACS as well as in those with CCS, the latter a term defining patients with stable coronary artery disease [9, $15-17]$. Whether $T_{\text {reg }}$ cells can function as new targets in atherosclerotic disease has become a subject of increasing interest [18]. However, it is still unclear why $\mathrm{T}_{\text {reg }}$ cells are reduced in patients with coronary artery disease but one intriguing possibility is that oxidative stress plays a major role. In a previous study, Mor et al. [16] demonstrated that the numbers of $\mathrm{CD} 44^{+} \mathrm{CD} 25^{+} \mathrm{T}_{\text {reg }}$ cells were markedly reduced after incubation with oxLDL while the effect on conventional $\mathrm{CD} 44^{+} \mathrm{CD} 25^{-} \mathrm{T}\left(\mathrm{T}_{\text {conv }}\right)$ cells was negligible. The finding indicating that $\mathrm{T}_{\text {reg }}$ cells were more sensitive to oxidative stress compared to $\mathrm{T}_{\text {conv }}$ cells was however contradicted by Mougiakakos et al. [19] who showed that $\mathrm{T}_{\text {reg }}$ cells from healthy volunteers were more resistant to hydrogen peroxide $\left(\mathrm{H}_{2} \mathrm{O}_{2}\right)$-induced cell death compared to $\mathrm{T}_{\text {conv }}$ cells.

The extent to which oxidative stress affects $T_{\text {reg }}$ cell survival in coronary artery disease is thus far from clarified. In this pilot study, we tested the hypothesis that oxidative stress is a contributor to the $\mathrm{T}_{\text {reg }}$ cell deficit in
CCS patients. Our first aim was to perform a comparison between $T_{\text {reg }}$ and $T_{\text {conv }}$ cells with respect to sensitivity towards oxidative stress. A second aim was to investigate whether $\mathrm{T}_{\text {reg }}$ and $\mathrm{T}_{\text {conv }}$ cells from CCS patients and healthy controls differed in their sensitivity towards oxidative stress. Different aspects of oxidative stress response were examined in freshly isolated $\mathrm{T}_{\text {reg }}$ and $\mathrm{T}_{\text {conv }}$ cells. We studied the sensitivity to oxidative stressinduced cell death ex vivo by treating cells with $\mathrm{H}_{2} \mathrm{O}_{2}$, a major member of the ROS family. We also determined the impact of $\mathrm{H}_{2} \mathrm{O}_{2}$ on cellular oxidative stress by measuring total (cytoplasmic and nuclear) cellular ROS at the single cell level. To further elucidate the oxidative stress response in vivo, we measured the expression and secretion of endogenous antioxidants in $\mathrm{T}_{\text {reg }}$ and $\mathrm{T}_{\text {conv }}$ cells from patients and controls.

\section{Methods}

\section{Study population}

The study population consisted of patients $(n=30)$ recruited from the Department of Cardiology, University Hospital, Linköping, Sweden, as well as control subjects with approximately equal sex and age distribution $(\mathrm{n}=24)$. All patients had significant coronary artery disease, defined as $\geq 50 \%$ luminal narrowing in any of the major epicardial coronary arteries (i.e., the right coronary artery, left anterior descending artery, and left circumflex artery), and a history of coronary event, i.e. ACS or stable angina followed by coronary revascularization. For the control group, individual residents of Linköping were randomly selected from the Swedish Population Register and invited to participate in the study. Individuals who accepted the invitation were included as controls if they were anamnestically healthy and had normal routine laboratory tests. Use of lipid-lowering or antihypertensive drugs for primary prevention of cardiovascular disease was allowed in the control group.

Study subjects were excluded if they suffered from severe heart failure, immunological disorders, neoplastic disease, had evidence of acute or recent ( $<2$ months) infection or major trauma, had undergone surgery/revascularization procedure ( $<2$ months) or received regular treatment with immunosuppressive or anti-inflammatory agents (except low-dose aspirin).

\section{Cell isolation}

Peripheral blood mononuclear cells (PBMCs) were isolated from diluted sodium heparinized whole blood using Ficoll-Paque Density Gradient Medium (ThermoFisher Scientific) as previously described [20]. An EasySep Human $\mathrm{CD} 44^{+} \mathrm{CD} 127^{\text {low }} \mathrm{CD} 25^{+}$Regulatory $\mathrm{T}$ Cell Isolation Kit (STEMCELL Technologies) was used according to manufacturer's instructions on 
PBMCs resulting in two cell fractions; $\mathrm{T}_{\text {reg }}$ cells defined as $\mathrm{CD} 44^{+} \mathrm{CD} 127^{\text {low }} \mathrm{CD} 25^{+}$and $\mathrm{T}_{\text {conv }}$ cells defined as $\mathrm{CD} 4{ }^{+} \mathrm{CD} 127^{+} \mathrm{CD} 25^{-} \mathrm{T}$ cells. After isolation cells were resuspended in complete RPMI (Fisher Scientific) with 10\% FBS (Fisher Scientific) and 2\% Penicillin Streptomycin solution (Fisher Scientific).

\section{Purity checks}

For purity checks, cells were stained with a Human Regulatory $\mathrm{T}$ Cell Sorting Kit cocktail including CD45RA-FITC, CD127-Alexa Fluor647, CD25-PE, and CD4-PerCP-Cy5.5 (BD Biosciences) and analysed on a FACS aria (BD Biosciences). Cells were separately stained for FoxP3 expression using a Human FoxP3 Buffer Set (BD Biosciences) together with antibodies against CD4FITC and FoxP3-V450 and analysed with Gallios flow cytometer (Beckman Coulter). Illustrative results are shown in Additional file 1: Figure S1.

\section{$\mathrm{H}_{2} \mathrm{O}_{2}$-induced cell death of $\mathrm{T}_{\text {reg }}$ and $\mathrm{T}_{\text {conv }}$ cells}

A total of $40,000 \mathrm{~T}_{\text {reg }}$ or $\mathrm{T}_{\text {conv }}$ cells were treated with 5 , 10 , 20, or $30 \mu \mathrm{M} \mathrm{H}_{2} \mathrm{O}_{2}$ or left untreated in a total volume of $200 \mu \mathrm{L}$ in a round-bottom 96-well plate. Cells were incubated for $18 \mathrm{~h}$ in a humified incubator at $37^{\circ} \mathrm{C}$ and $5 \% \mathrm{CO}_{2}$. The incubation time was chosen based on previous similar studies [19, 21]. Following incubation, cells were washed and $100 \mu \mathrm{L}$ Annexin-V Binding Buffer (BD Biosciences), Annexin-V PE and CD4-BV510 antibodies (BD Biosciences) was added. After 15 min $400 \mu \mathrm{L}$ Annexin-V Binding Buffer and SYTOX Red Dead Cell Stain (ThermoFisher) was added. After another $10 \mathrm{~min}$, cells were analyzed within $1 \mathrm{~h}$ with a Gallios flow cytometer to monitor cell death.

\section{Staurosporin-induced cell apoptosis of Tregand $\mathrm{T}_{\text {conv }}$ cells} In the same manner as described above, $\mathrm{T}_{\text {reg }}$ and $\mathrm{T}_{\text {conv }}$ cell fractions were also treated with $2.5 \mu \mathrm{M}$ staurosporin (STS) (Streptomyces sp. Origin, Sigma-Aldrich) as an alternative way to induce apoptosis.

$\mathrm{H}_{2} \mathrm{O}_{2}$-induced intracellular ROS levels in $\mathrm{T}_{\text {reg }}$ and $\mathrm{T}_{\text {conv }}$ cells A total of $40000 \mathrm{~T}_{\text {reg }}$ or $\mathrm{T}_{\text {conv }}$ cells were treated with $30 \mu \mathrm{M}, 60 \mu \mathrm{M}$ and $120 \mu \mathrm{M} \mathrm{H}_{2} \mathrm{O}_{2}$ at $37^{\circ} \mathrm{C}$ for a total of $2 \mathrm{~h}$. After $1 \mathrm{~h}$, CellROX Green (Thermofisher), a measure of total (cytoplasmic and nuclear) cellular ROS, was added. Thereafter cells were washed with $\mathrm{PBS}+\mathrm{O} .5 \%$ FBS and and resuspended in $100 \mu \mathrm{L}$ PBS $+0.5 \%$ FBS and SYTOX Red Dead Cell Stain, CD4BV510 and $10 \mu \mathrm{L}$ Brilliant Stain Buffer (BD Biosciences) were added and kept for 15 in in the dark in room temperature. Finally, mean fluorescence intensity (MFI) of CellROX Green was recorded with a 3-laser Gallios Flow Cytometer.

\section{Flow cytometry analyses}

Flow cytometry data were analyzed with Kaluza Analysis Software 2.1 (Beckman Coulter). Lymphocytes were gated according to size and granularity and thereafter $\mathrm{CD}^{+}$cells only were gated. Annexin-V identified early apoptosis while SYTOX identified late apoptosis and necrosis. An illustrative example is shown in Additional file 2: Figure S2. Cells negative for Annexin-V and SYTOX were considered viable. For the oxidative stress assay, cells were gated in a lymphocyte gate and the CellROX Green signal was recorded in $\mathrm{CD}^{+}$cells that were negative for SYTOX, i.e. living cells.

\section{Oxidative stress gene expression in circulating $\mathrm{T}_{\text {reg }}$ and $T_{\text {conv }}$ cells}

mRNA expression of oxidative stress-associated genes was assessed in $\mathrm{T}_{\text {reg }}$ and $\mathrm{T}_{\text {conv }}$ cells isolated from PBMCs using the same kit from STEMCELL as described above. Cell lysates were collected directly after isolation. Total RNA was isolated using Qiagen total RNA isolation kit (Thermofisher). The RNA (total 21,6 ng) was converted to cDNA using high capacity cDNA reverse transcription kit with an RNAse inhibitor (Life Technologies). cDNA was amplified by RT-PCR reactions with TaqMan ${ }^{\mathrm{TM}}$ Fast Universal PCR Mastermix (Life Technologies) on an ABI 7500 Sequence Detector (Applied Biosystems). The following TaqMan Gene Expression Assay kits were used: Hs00167309_m1 for superoxide dismutase 2 (SOD2), Hs00156308_m1 for catalase (CAT), Hs00757844_m1 for oxidation resistance 1 (OXR1), Hs04194449_s1 for glutathione peroxidase-7 (GPX7), Hs00828652_m1 for thioredoxin (Trx), Hs00917067_m1 thioredoxin reductase (TrxR1). Eukaryotic 18S rRNA (Part number: 4352930E) served as endogenous control. The expression of all genes was calculated with the comparative CT method where the amount of target, normalized to an endogenous reference and relative to a calibrator, is given by $2^{\Delta \Delta C T}$ according to the user bulletin no 2 (Applied Biosystems). Results are presented as arbitrary units. Each sample was run in duplicates and a maximum deviation of $10 \%$ was allowed.

\section{TrxR1 in cell supernatants}

The concentration of TrxR1 in cell supernatants from $\mathrm{T}_{\text {reg }}$ and $\mathrm{T}_{\text {conv }}$ cells after treatment with or without $30 \mu \mathrm{M}$ $\mathrm{H}_{2} \mathrm{O}_{2}$ for $18 \mathrm{~h}$ was measured with an ELISA kit (Abcam, UK) according to manufacturer's instructions. The range of the standard curve was $0.196-25 \mathrm{ng} / \mathrm{mL}$. Samples were assayed in duplicates and a maximal deviation of $15 \%$ was allowed. Undetected samples were given half the value of the lowest standard point. 


\section{Total antioxidant capacity in PBMCs}

Total antioxidant capacity (TAC) in PBMCs was measured using Cell Biolabs, Inc. OxiSelect Total Antioxidant Capacity Assay Kit. In brief, cell pellets of 3 millions PBMCs were snap frozen and stored in $-80{ }^{\circ} \mathrm{C}$ for no longer than 2 weeks. Frozen PBMCs were lysed by thawing on ice followed by water-bath sonication for $10 \mathrm{~min}$ and thereafter kept on ice. The TAC assays were then performed according to manufacturer's instructions. Results are expressed as units of uric acid equivalents (UAE).The TAC results were also normalized by protein amount measured in PBMCs using Thermo Scientific's Coomassie Plus (Bradford) Assay Kit according to the manufacturer's instruction. The final TAC results were calculated according to the equation below:

$$
\mathrm{TAC}=(\mathrm{UAE} / 100 \mu \mathrm{g})=\frac{\text { UAE }}{\text { Protein Amount Assay }(\mu \mathrm{g})} \times 100
$$

\section{Oxidized LDL cholesterol in plasma}

OxLDL in EDTA plasma was measured by an ELISA (Mercodia, Uppsala, Sweden), which is a capture ELISA using the mAb-4E6 antibody against a conformational epitope in oxidized ApoB-100, developed by Holvoet et al.[22]. The inter-assay variation was below $5 \%$ for the oxLDL ELISA. All samples were within the range of detection. The oxLDL/LDL ratio was used as an estimate of in vivo LDL oxidation [23].

\section{Statistics}

Statistical analyses were calculated in IBM SPSS Statistics 25. Groups and independent variables were compared using independent Mann-Whitney U tests, Fisher's exact test, and a Chi Square test. Wilcoxon rank sum test or paired t-test were used to compare paired data. Correlations were calculated using Spearman rank correlation test. Numeric data are presented as median and inter-quartile range. A p value $<0.05$ was considered significant. Sample size calculation was based on a previous study showing that natural killer cells in CCS patients were more sensitive to apoptosis induced by oxidized lipids compared to natural killer cells in healthy controls [24].

\section{Results}

Characteristics of study population

The basal characteristics of the study population are presented in Table 1 . There were no significant differences

Table 1 Basal characteristics of CCS patients and controls

\begin{tabular}{|c|c|c|c|}
\hline & CCS patients $(n=30)$ & Controls $(n=24)$ & $p$ \\
\hline Age, years & $67(62-73)$ & $73(67-75)$ & 0.053 \\
\hline Males & $23(77)$ & $17(71)$ & 0.429 \\
\hline Body mass index, $\mathrm{kg} / \mathrm{m}^{2}$ & $27(24-30)$ & $25(24-28)$ & 0.192 \\
\hline \multicolumn{4}{|l|}{ Smoking } \\
\hline Current & $1(3.3)$ & $0(0)$ & 0.556 \\
\hline Former & $15(50)$ & $3(13)$ & 0.004 \\
\hline History of coronary event, ACS/SA & $23(77) / 7(23)$ & - & \\
\hline History of coronary revascularization, $\mathrm{PCI} / \mathrm{CABG}^{\mathrm{a}}$ & $19(63) / 15(50)$ & - & \\
\hline Severity of coronary artery disease, 1VD/2VD/3VD & $7(23) / 9(30) / 14(47)$ & - & \\
\hline Use of anti-hypertensive drugs & $14(47)$ & $8(33)$ & 0.239 \\
\hline Use of statin & $29(97)$ & $7(29)$ & $<0.0001$ \\
\hline LDL cholesterol, mmol/L & $1.6(1.4-1.9)$ & $3(2.2-3.5)$ & $<0.0001$ \\
\hline oxLDL cholesterol, U/L & $43(38-53)$ & $68(55-75)$ & $<0.0001$ \\
\hline oxLDL/LDL ratio & $29(24-35)$ & $22(20-27)$ & 0.006 \\
\hline HDL cholesterol, mmol/L & $1.4(1.0-1.7)$ & $1,4(1.0-1.7)$ & 0.662 \\
\hline Triglycerides, mmol/L & $1.0(0.7-1.5)$ & $1.3(0.8-1.6)$ & 0.398 \\
\hline Creatinine, $\mu \mathrm{mol} / \mathrm{L}$ & $88(78-97)$ & $79(73-92)$ & 0.134 \\
\hline Fasting glucose, mmol/L & $5.8(5.3-6.6)$ & $5.7(5.2-6.3)$ & 0.403 \\
\hline TAC in PBMCs, UAE/100 ug & $0.97(0.28-1.48)$ & $1.53(1.20-2.09)$ & 0.001 \\
\hline
\end{tabular}

Values are given as $\mathrm{n}(\%)$ or median (interquartile range). CCS: chronic coronary syndrome; ACS: acute coronary syndrome; SA: stable angina; PCI: percutaneous coronary intervention; CABG; coronary artery bypass grafting; VD: vessel disease; LDL: low density lipoprotein; oxLDL: oxidized LDL; HDL: high density lipoprotein; TAC: total antioxidant capacity; PBMC: peripheral blood mononuclear cell; UAE: uric acid equivalents

${ }^{a}$ Four patients had a previous history of PCI followed by CABG

b Severity of coronary artery disease is indicated as $\geq 50 \%$ luminal narrowing in one, two or three major epicardial coronary arteries (i.e., the right coronary artery, left anterior descending artery, and left circumflex artery). Bolded $P$-values represent statistical significance 
between CCS patients and controls with respect to age, gender, body mass index, current smoking, use of anti-hypertensive medication or laboratory variables, including high density lipoprotein (HDL) cholesterol, triglycerides, creatinine or fasting glucose levels. The prevalence of former smoking was higher among patients. Seven (23\%) patients had type 2 diabetes. Twenty-three (77\%) patients had a history of ACS. As regards coronary revascularization, 19 (63\%) patients had a history of percutaneous coronary intervention (PCI), 15 (50\%) had a history of coronary artery bypass grafting (CABG) while 4 (13\%) had a history of previous PCI followed by CABG. Statins were used by all patients (except for one) resulting in significantly lower LDL levels in this group. Also, the levels of oxLDL were lower in patients. However, the oxLDL/LDL ratios were significantly higher indicating an environment of oxidative stress in the patient group. Moreover, the TAC levels in PBMCs were significantly lower in patients compared to controls, $p=0.001$. When the 7 patients with diabetes were excluded, the TAC levels were still significantly lower in patients, $p=0.002$.

\section{$\mathrm{H}_{2} \mathrm{O}_{2}$ - and STS-induced cell death of $\mathrm{T}_{\text {reg }}$ and $\mathrm{T}_{\text {conv }}$ cell}

$\mathrm{T}_{\text {reg }}$ and $\mathrm{T}_{\text {conv }}$ cells were isolated from 34 subjects (20 CCS patients and 14 controls). Among patients, 16 had a history of ACS (7 PCI, 9 CABG, 4 PCI followed by CABG) and 4 had a history of stable angina (2 PCI, 2 CABG). Separate fractions of $\mathrm{T}_{\text {reg }}$ and $\mathrm{T}_{\text {conv }}$ cells were treated with medium only or increasing concentrations of $\mathrm{H}_{2} \mathrm{O}_{2}$. Before treatment, the viability was $>90 \%$ in both cell types. After $18 \mathrm{~h}$ incubation with medium only, the proportions of living $\mathrm{T}_{\text {reg }}$ cells were significantly lower compared with $\mathrm{T}_{\text {conv }}$ cells, 71 (64-76) \% vs 90 (86-93) \%, $\mathrm{p}<0.001$. At all concentrations of $\mathrm{H}_{2} \mathrm{O}_{2}, \mathrm{~T}_{\text {reg }}$ cells were more susceptible to $\mathrm{H}_{2} \mathrm{O}_{2}$-induced cell death than $\mathrm{T}_{\text {conv }}$ cells (Fig. 1A). There was a clear dose-response relationship with very low percentages of living $\mathrm{T}_{\text {reg }}$ cells at 20 and $30 \mu \mathrm{M} \mathrm{H}_{2} \mathrm{O}_{2}$.

$\mathrm{T}_{\text {reg }}$ cells were also more susceptible to cell death compared to $\mathrm{T}_{\text {conv }}$ cells when STS, a classical inducer of the intrinsic apoptotic pathway, was used. The proportions of living cells were $46(37-54) \%$ and 88 (79-95) \%, p < 0.001 , for $\mathrm{T}_{\text {reg }}$ and $\mathrm{T}_{\text {conv }}$ cells, respectively, after treatment with $2.5 \mu \mathrm{M}$ STS

There were no significant differences in susceptibility to $\mathrm{H}_{2} \mathrm{O}_{2}$-induced cell death between $\mathrm{T}_{\text {reg }}$ cells from CCS patients and $\mathrm{T}_{\text {reg }}$ cells from controls at any concentration of $\mathrm{H}_{2} \mathrm{O}_{2}$ (Table 2). Neither were there any differences in STS-induced cell death in $\mathrm{T}_{\text {reg }}$ cells between patients and controls. On the other hand, the percentages of living $\mathrm{T}_{\text {conv }}$ cells were significantly lower in patients than in controls when $\mathrm{T}_{\text {conv }}$ cells were exposed to $\mathrm{H}_{2} \mathrm{O}_{2}$ at lower concentrations $(5$ or $10 \mu \mathrm{M})$ or to STS (Table 2).

\section{$\mathrm{H}_{2} \mathrm{O}_{2}$-induced intracellular ROS accumulation in $\mathrm{T}_{\text {reg }}$ and $\mathrm{T}_{\text {conv }}$ cells}

$\mathrm{H}_{2} \mathrm{O}_{2}$-induced intracellular ROS levels were measured in $\mathrm{T}_{\text {reg }}$ and $\mathrm{T}_{\text {conv }}$ cells after $2 \mathrm{~h}$ treatment in medium with or without increasing concentrations of $\mathrm{H}_{2} \mathrm{O}_{2}$. Treatment with medium only or with $10 \mu \mathrm{M} \mathrm{H}_{2} \mathrm{O}_{2}$ did not reveal any differences between $\mathrm{T}_{\text {reg }}$ and $\mathrm{T}_{\text {conv }}$ cells regardless of subject types while the ROS accumulation was significantly larger in $\mathrm{T}_{\text {reg }}$ cells treated with $30 \mu \mathrm{M} \mathrm{H}_{2} \mathrm{O}_{2}$ or more (Fig. 1B). When we compared CCS patients and controls,
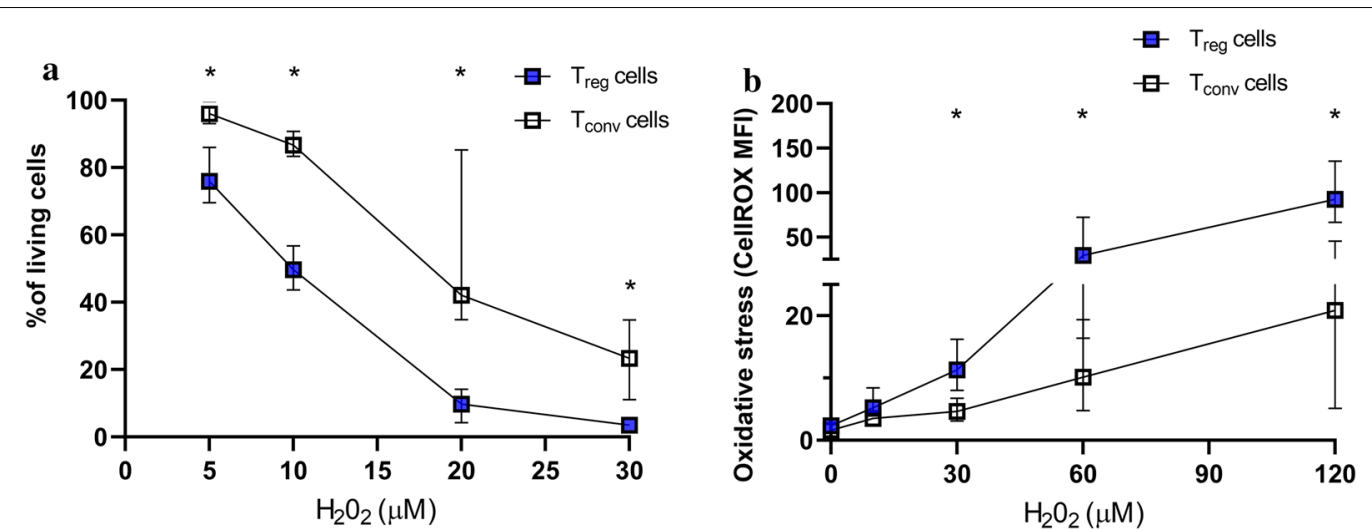

Fig. 1 The response to oxidative stress ex vivo in $T_{\text {reg }}$ and $T_{\text {conv }}$ cells. A Percentages of living $T_{\text {reg }}$ and $T_{\text {conv }}$ cells, following treatment with 5, 10, 20, or $30 \mu \mathrm{M} \mathrm{H}_{2} \mathrm{O}_{2}$ for $18 \mathrm{~h}$. \% of living cells is defined as negative for Annexin-V and SYTOX and normalized based on untreated cells (medium only). Asterisks indicate significant differences between $T_{\text {reg }}$ and $T_{\text {conv }}$ cells, all $p<0.0001$. Number of study subjects per dose of $\mathrm{H}_{2} \mathrm{O}_{2}$ were $n=19$ for $5 \mu \mathrm{M}$, $\mathrm{n}=33$ for $10 \mu \mathrm{M}, \mathrm{n}=22$ for $20 \mu \mathrm{M}, \mathrm{n}=34$ for $30 \mu \mathrm{M}$. B The levels of oxidative stress, measured as mean fluorescence intensity (MFI) of CellROX Green, is shown in $\mathrm{T}_{\text {reg }}$ and $\mathrm{T}_{\text {conv }}$ cells following treatment with $0,10,30,60$ or $120 \mu \mathrm{M} \mathrm{H}_{2} \mathrm{O}_{2}$ for $2 \mathrm{~h}$ (B). Asterisks indicate significant differences between $T_{\text {reg }}$ and $T_{\text {conv }}$ cells, all $p<0.0001$ (except for $60 \mu \mathrm{M} \mathrm{H}_{2} \mathrm{O}_{2}, p<0.001$ ). Number of study subjects per dose of $\mathrm{H}_{2} \mathrm{O}_{2}$ were $\mathrm{n}=22 \mathrm{for} 0 \mu \mathrm{M}, \mathrm{n}=3$ for $10 \mu \mathrm{M}, \mathrm{n}=20$ for $30 \mu \mathrm{M}, \mathrm{n}=20$ for $60 \mu \mathrm{M}, \mathrm{n}=12$ for $120 \mu \mathrm{M}$. Box plots display median and $\mathrm{i}$-q range values 
Table 2 Percentages of living regulatory $T\left(T_{\text {reg }}\right)$ cells and corresponding conventional $T\left(T_{\text {conv }}\right)$ cells from CCS patients and controls, defined as negative for Annexin-V and SYTOX and normalized based on untreated cells (medium only), after $18 \mathrm{~h}$ treatment with different concentrations of $\mathrm{H}_{2} \mathrm{O}_{2}$ or $2,5 \mu \mathrm{M}$ STS

\begin{tabular}{llll}
\hline Treatment & CCS patients $(\mathbf{n}=\mathbf{2 0})$ & Controls $(\mathbf{n}=\mathbf{1 4})$ & $\boldsymbol{p}$ \\
& $\mathbf{T}_{\text {reg }}$ cells, \% living cells & \\
\hline $5 \mu \mathrm{M} \mathrm{H}_{2} \mathrm{O}_{2}$ & $74(69-88)$ & $88(77-94)$ & 0.246 \\
$10 \mu \mathrm{M} \mathrm{H}_{2} \mathrm{O}_{2}$ & $50(44-58)$ & $58(41-79)$ & 0.338 \\
$20 \mu \mathrm{M} \mathrm{H}_{2} \mathrm{O}_{2}$ & $9.6(2.8-11)$ & $14(8.8-29)$ & 0.159 \\
$30 \mu \mathrm{M} \mathrm{H}_{2} \mathrm{O}_{2}$ & $2.7(2.2-4.2)$ & $3.9(2.8-8.9)$ & 0.106 \\
$2.5 \mu \mathrm{M} \mathrm{STS}$ & $42(30-52)$ & $47(40-56)$ & 0.174 \\
\hline & $\mathrm{T}_{\text {conv }}$ cells, \% living cells & \\
\hline $5 \mu \mathrm{M} \mathrm{H}_{2} \mathrm{O}_{2}$ & $94(92-99)$ & $98(97-100)$ & $\mathbf{0 . 0 4 6}$ \\
$10 \mu \mathrm{M} \mathrm{H}_{2} \mathrm{O}_{2}$ & $85(92-99)$ & $93(87-98)$ & $\mathbf{0 . 0 3 0}$ \\
$20 \mu \mathrm{M} \mathrm{H}_{2} \mathrm{O}_{2}$ & $39(35-67)$ & $69(45-84)$ & 0.110 \\
$30 \mu \mathrm{M} \mathrm{H}_{2} \mathrm{O}_{2}$ & $24(11-41)$ & $39(21-57)$ & 0.199 \\
$2.5 \mu \mathrm{M} \mathrm{STS}$ & $80(69-91)$ & $91(88-95)$ & $\mathbf{0 . 0 1 4}$ \\
\hline
\end{tabular}

Values are given as median (inter-quartile range). CCS, chronic coronary syndrome, $\mathrm{H}_{2} \mathrm{O}_{2}$ : hydrogen peroxide; STS: staurosporin; Bolded $P$-values represent statistical significance

the ROS production in $\mathrm{T}_{\text {reg }}$ and $\mathrm{T}_{\text {conv }}$ cells did not show any significant differences (Additional file 3: Figures S3A and B).

The in vivo expression of oxidative stress-associated genes in $\mathrm{T}_{\text {reg }}$ and $\mathrm{T}_{\text {conv }}$ cells

In order to compare the oxidative stress response in vivo, we measured the expression of a number of oxidative stress-associated genes in freshly isolated $\mathrm{T}_{\text {reg }}$ and $\mathrm{T}_{\text {conv }}$ cells from 20 subjects, 10 CCS patients ( 8 males, 2 females, median age 67, 7 with a previous history of ACS and 4 with a history of CABG) and 10 controls (8 males, 2 females, median age 68). As shown in Fig. 2A, the mRNA levels of CAT, OXR1, Trx and TrxR1 were significantly higher in $\mathrm{T}_{\text {reg }}$ cells than in $\mathrm{T}_{\text {conv }}$ cells regardless of subject types while mRNA levels of GPX7 and SOD2 expression did not differ between the two T cell fractions (Fig. 2B).

When comparing CCS patients and controls, the $\mathrm{T}_{\text {reg }}$ cells did not show any significant differences in gene expression (Table 3 ). On the other hand, the $\mathrm{T}_{\text {conv }}$ cells from CCS patients showed significantly higher expression of TrxR1 than those from controls $(p=0.033)$. Also, the Trx and SOD2 mRNA levels tended to be higher in $\mathrm{T}_{\text {conv }}$ cells from patients $(\mathrm{p}=0.104$ and $\mathrm{p}=0.091$, respectively).

\section{Secretion of TrxR1 by $\mathrm{T}_{\text {reg }}$ and $\mathrm{T}_{\text {conv }}$ cells}

In order to further confirm the changes in gene expression, we measured TrxR1 protein levels in supernatants from $\mathrm{T}_{\text {reg }}$ and $\mathrm{T}_{\text {conv }}$ cells collected from 32 subjects (18 CCS patients and 14 controls). The reason for measuring TrxT1 relied on a previous study by Xie et al. [25].
The Trx1 levels were generally low and almost undetectable in untreated samples. However, both $\mathrm{T}_{\text {reg }}$ and $\mathrm{T}_{\text {conv }}$ cells secreted significantly more TrxR1 after $\mathrm{H}_{2} \mathrm{O}_{2}$ treatment, $\mathrm{p}<0.0001$ in both cell types. Also, TrxR1 levels were significantly higher in supernatants from $\mathrm{T}_{\text {reg }}$ cells compared to $\mathrm{T}_{\text {conv }}$ cells, $\mathrm{p}=0.003$ (Fig. 2C). There were no differences between CCS patients and controls (Additional file 3: Figure S3).

\section{Correlations}

There were significant inverse relationships between $\mathrm{H}_{2} \mathrm{O}_{2}$-induced intracellular ROS levels and \% of living cells after $18 \mathrm{~h}$, in particular for $\mathrm{T}_{\text {conv }}$ cells (Table 4). There was no correlation between intracellular ROS levels and STS-induced cell death. We were not able to study correlations between susceptibility to $\mathrm{H}_{2} \mathrm{O}_{2}$ ex vivo and antioxidant gene expression since these analyses were performed in different study subjects.

TAC levels in freshly isolated PBMCs were measured in all study subjects and correlated inversely with intracellular ROS levels after $2 \mathrm{~h}$ treatment with $60 \mu \mathrm{M}$ $\mathrm{H}_{2} \mathrm{O}_{2}$ in $\mathrm{T}_{\text {reg }}$ cells, $r=-0.480, p=0.037$; and $\mathrm{T}_{\text {conv }}$ cells, $r=-0.511, p=0.030$, but showed no correlations with $\mathrm{H}_{2} \mathrm{O}_{2}$-induced cell death ex vivo or with antioxidant gene expression.

\section{Discussion}

The main findings from the present study are that human $\mathrm{T}_{\text {reg }}$ cells exhibit markedly increased sensitivity to $\mathrm{H}_{2} \mathrm{O}_{2}$-induced ROS production and cell death compared to $\mathrm{T}_{\text {conv }}$ cells in both CCS patients and healthy controls. $\mathrm{T}_{\text {reg }}$ cells were also more sensitive to spontaneous 

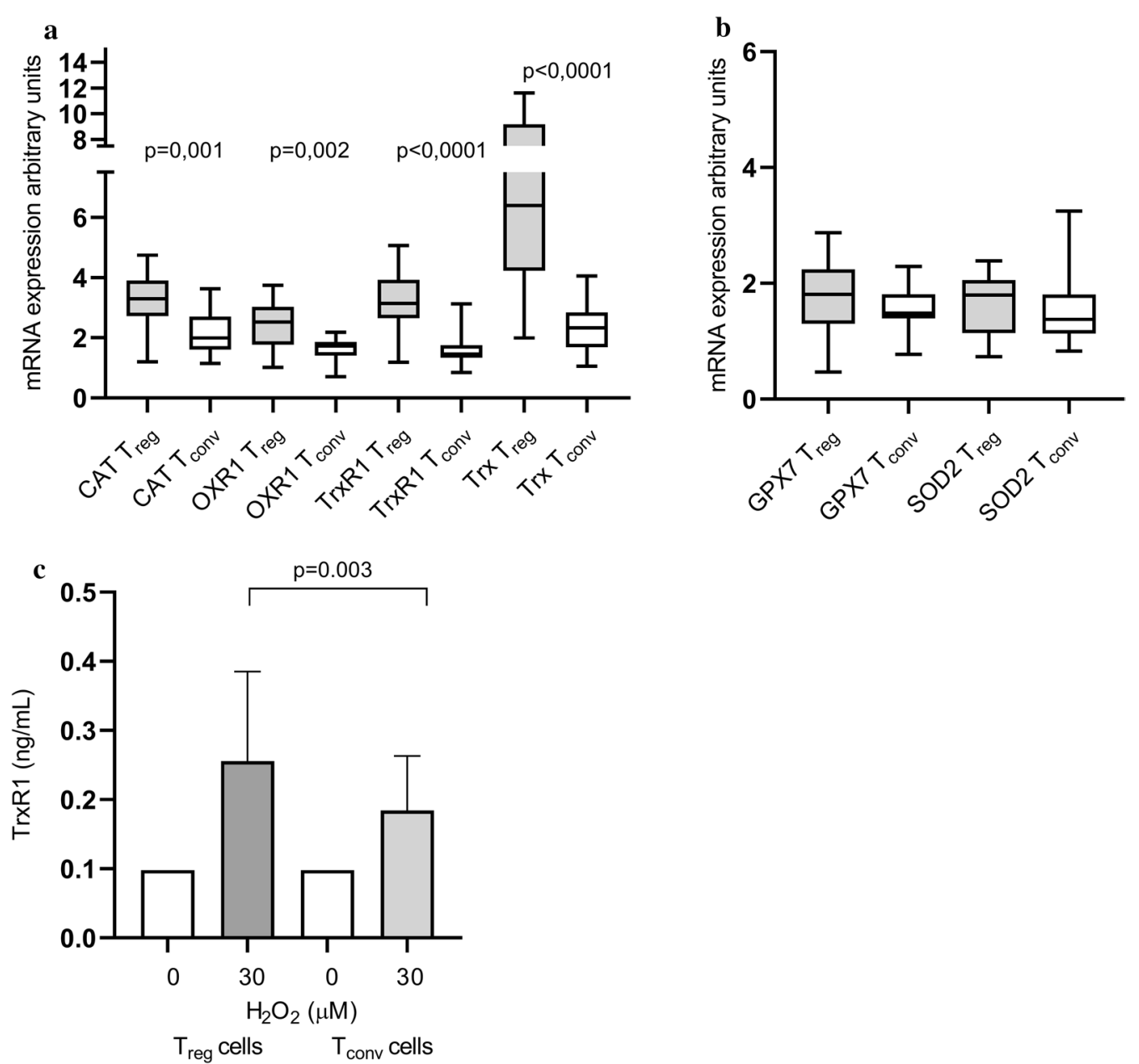

Fig. 2 The expression of oxidative stress-associated genes in $T_{\text {reg }}$ and $T_{\text {conv }}$ cells from 20 study subjects (10 CCS patients and 10 controls). A Genes with significant differences between patients and controls included catalase (CAT), oxidation resistance 1 (OXR1), thioredoxin reductase-1 (TrxR1) and thioredoxin (TrX). B Genes with non-significant differences included glutathione peroxidase 7 (GPX7) and superoxide dismutase 2 (SOD2). Graphs depict arbitrary values normalized against internal control and 18S rRNA in each individual sample. C Thioredoxin reductase 1 (TrxR1) (ng/ $\mathrm{mL}$ ) levels in cell supernatants of $\mathrm{T}_{\text {reg }}$ and $\mathrm{T}_{\text {conv }}$ cells treated with either 0 or $30 \mu \mathrm{M} \mathrm{H}_{2} \mathrm{O}_{2}$. Number of study subjects per dose of $\mathrm{H}_{2} \mathrm{O}_{2}$ were $\mathrm{n}=32 \mathrm{for}$ $0 \mu \mathrm{M}$ and $\mathrm{n}=32$ for $30 \mu \mathrm{M}$. In all figures, box plots and bars display median and i-q range values'

cell death when cultured in medium overnight and to cell death induced by STS, a potent inducer of apoptosis. Hitherto, the impact of oxidative stress on human $\mathrm{T}_{\text {reg }}$ cells has been far from clarified. The existing literature is both sparse and inconsistent. Mor et al. [16] reported that the number of $\mathrm{T}_{\text {reg }}$ cells was reduced to a considerably larger extent than the number of $\mathrm{T}_{\text {conv }}$ cells after in vitro incubation with oxidized LDL. They further showed that this effect was attenuated in the presence of caspase inhibitor suggesting that apoptosis contributed to the loss of cells. Several other studies have demonstrated that $\mathrm{T}_{\text {reg }}$ cells are more prone to apoptosis than $\mathrm{T}_{\text {conv }}$ cells when they are cultured in medium only [26-28]. On the other hand, Mougiakakos et al. [19] treated T cells with 5, 10 or $20 \mu \mathrm{M} \mathrm{H}_{2} \mathrm{O}_{2}$ for $18 \mathrm{~h}$ and found that $\mathrm{T}_{\text {reg }}$ cells were significantly more resistant to $\mathrm{H}_{2} \mathrm{O}_{2}$-induced cell death compared to $\mathrm{T}_{\text {conv }}$ cells. Moreover, they found that naïve $T_{\text {reg }}$ cells were more resistant than memory $\mathrm{T}_{\text {reg }}$ cells. One possible explanation for the contradictory results may be the choice of study subjects. Mougiakakos et al. [19] used cells from a few healthy donors of unknown age while we used cells from sick and elderly subjects. Ageing and cardiovascular disease are both linked to elevated oxidative stress. We previously showed that naïve $\mathrm{T}_{\text {reg }}$ cells constituted only $15 \%$ of all $\mathrm{T}_{\text {reg }}$ cells in elderly CAD patients as opposed to $25 \%$ in age-matched controls, and also that the function of naïve as well as memory $\mathrm{T}_{\text {reg }}$ cells was impaired in patients, 
Table 3 The mRNA expression of thioredoxin reductase-1 (TrxR1), thioredoxin (Trx), glutathione peroxidase 7 (GPX7), oxidation resistance 1 (OXR1), catalase (CAT) and superoxide dismutase 2 (SOD2) in regulatory $T\left(T_{\text {reg }}\right)$ cells and corresponding conventional $T$ $\left(T_{\text {conv }}\right)$ cells from CCS patients and controls

\begin{tabular}{llll}
\hline Gene & CCS patients $(\mathbf{n}=\mathbf{1 0})$ & Controls $\mathbf{n}=\mathbf{1 0})$ & \\
\hline TrxR1 & $\mathbf{T}_{\text {reg }}$ cells & & $\mathbf{P}$ \\
Trx & $3.7(2.6-4.4)$ & $3.0(2.6-3.9)$ & 0.973 \\
GPX7 & $7.9(4.6-10)$ & $6.2(4.0-6.7)$ & 0.445 \\
OXR1 & $2.0(1.2-2.2)$ & $1.6(1.3-2.4)$ & 0.621 \\
CAT & $2.9(1.8-3.3)$ & $2.5(1.7-2.7)$ & 0.681 \\
SOD2 & $3.6(2.4-4.0)$ & $3.1(2.8-3.9)$ & 0.929 \\
\hline & $1.9(1.1-2.0)$ & $1.7(1.2-2.1)$ & 0.949 \\
\hline TrXR1 & $\mathbf{T}_{\text {conv }}$ cells & & 0.033 \\
TrX & $1.7(1.4-2.0)$ & $1.4(1.0-1.6)$ & 0.104 \\
GPX7 & $2.8(2.2-3.2)$ & $1.9(1.5-2.4)$ & 0.267 \\
OXR1 & $1.4(1.4-2.1)$ & $1.5(1.4-1.7)$ & 0.601 \\
CAT & $1.8(1.4-1.9)$ & $1.7(1.4-1.9)$ & 0.204 \\
SOD2 & $2.4(1.9-2.7)$ & $1.7(1.4-2.8)$ & 0.091 \\
\hline
\end{tabular}

Values are given as median (interquartile range). CCS, chronic coronary syndrome, Bolded P-value represents statistical significance

Table 4 Relationships between $\mathrm{H}_{2} \mathrm{O}_{2}$-induced intracellular ROS levels after $2 \mathrm{~h}$ treatment with $60 \mu \mathrm{M} \mathrm{H}_{2} \mathrm{O}_{2}$ and \% of living cells after $18 \mathrm{~h}$ with increasing doses of $\mathrm{H}_{2} \mathrm{O}_{2}$ in regulatory $\mathrm{T}\left(\mathrm{T}_{\text {reg }}\right)$ cells and corresponding conventional $\mathrm{T}\left(\mathrm{T}_{\text {conv }}\right)$ cells

\begin{tabular}{lll}
\hline Treatment & $\mathbf{T}_{\text {reg }}$ cells & $\mathbf{T}_{\text {conv }}$ cells \\
\hline $5 \mu \mathrm{M} \mathrm{H}_{2} \mathrm{O}_{2}$ & -0.091 & -0.067 \\
$10 \mu \mathrm{M} \mathrm{H}_{2} \mathrm{O}_{2}$ & -0.422 & $-0.571^{*}$ \\
$20 \mu \mathrm{M} \mathrm{H}_{2} \mathrm{O}_{2}$ & -0.336 & $-0.609^{*}$ \\
$30 \mu \mathrm{M} \mathrm{H}_{2} \mathrm{O}_{2}$ & $-0.530^{*}$ & $-0.652^{* *}$
\end{tabular}

Relationships are presented as Spearman correlation coefficients. ${ }^{*} \mathrm{p}<0.05$ ** $\mathrm{p}<0.01$

including lower suppressive capacity [9]. Differences in naïve $\mathrm{T}_{\text {reg }}$ cell pool size and function as well as individual variations in oxidative status may thus contribute to the disparity in results between our study and Mougiakakos et al. [19]. Still, important methodological aspects make it difficult to directly compare the studies. Mougiakakos et al. [19] used a different $\mathrm{T}_{\text {reg }}$ cell isolation protocol and they assessed cell death by labelling late apoptotic and necrotic cells, while we also included labelling of early apoptotic cells.

In an attempt to assess intrinsic ability of the cells to counteract oxidative stress, we measured the mRNA expression of several main antioxidant genes which all contribute to inactivate ROS, in freshly isolated $\mathrm{T}_{\text {reg }}$ and $\mathrm{T}_{\text {conv }}$ cells from both patients and controls. Collectively, the expression of catalase was significantly higher in $\mathrm{T}_{\text {reg }}$ cells than in $\mathrm{T}_{\text {conv }}$ cells and so was the expression of OXR1, a protein that has been described as a cellular oxidative stress sensor regulating the expression of several antioxidant enzymes [29]. Also, mRNA levels of the two main proteins, Trx and TrxR1, in the antioxidant Trx system were markedly upregulated in $\mathrm{T}_{\text {reg }}$ cells. Our findings partly agree with the previous study by Mougiakakos et al. [21], who reported that Trx expression was higher in $\mathrm{T}_{\text {reg }}$ cells compared with $\mathrm{T}_{\text {conv }}$ cells while, on the other hand, catalase expression did not differ in their small study group of volunteers. An earlier genomic and proteomic screening study examined the $\mathrm{H}_{2} \mathrm{O}_{2}$-induced gene and protein expression in human skin fibroblasts and reported that TrxR1 was the only oxidation-related candidate with elevated levels at both the mRNA and protein level, the latter measured in cell lysates [25]. Another study by Söderberg et al. [30] provided evidence that TrxR1 was secreted by human PBMCs upon inflammatory stimulation. Here, we were able to show that TrxR1 was secreted into the cell supernatant to a greater extent by $\mathrm{T}_{\text {reg }}$ cells than by $\mathrm{T}_{\text {conv }}$ cells upon $\mathrm{H}_{2} \mathrm{O}_{2}$ treatment. Altogether, our findings indicate that $\mathrm{T}_{\text {reg }}$ cells have a higher endogenous antioxidant capacity than $\mathrm{T}_{\text {conv }}$ cells in both CCS patients and controls.

Several studies have reported reduced levels of $\mathrm{T}_{\text {reg }}$ cells in peripheral blood of patients with ACS [9, 1517]. It has also been proposed that oxidative stress is involved in the depletion of $\mathrm{T}_{\text {reg }}$ cells. Mor et al. [16] showed that $\mathrm{T}_{\text {reg }}$ cells from ACS patients were more sensitive to oxidized LDL than $\mathrm{T}_{\text {reg }}$ cells from CCS patients or patients with normal coronary angiograms. 
A later study by Zhang et al. [17] showed that the spontaneous apoptosis of $\mathrm{T}_{\text {reg }}$ cells was pronounced in ACS patients and further demonstrated that oxLDL was able to induce apoptosis of human $\mathrm{T}_{\text {reg }}$ cells in vitro, yet without comparing $\mathrm{T}_{\text {reg }}$ and $\mathrm{T}_{\text {conv }}$ cells. Recently, we found that the numerical and functional $\mathrm{T}_{\text {reg }}$ cell deficit in ACS patients was not merely a transient phenomenon but that it remained after clinical stabilization [9]. In the present study, we therefore focused on the potential role of oxidative stress in the depletion of $\mathrm{T}_{\text {reg }}$ cells in CCS patients. However, there was no proof that $\mathrm{T}_{\text {reg }}$ cells from patients were more prone to $\mathrm{H}_{2} \mathrm{O}_{2}$-induced cell death than $\mathrm{T}_{\text {reg }}$ cells from controls, when assessed ex vivo. Moreover, the expression of antioxidant genes in freshly isolated $\mathrm{T}_{\text {reg }}$ cells from patients and controls indicated that $\mathrm{T}_{\text {reg }}$ cells in CCS patients and controls had similar levels of endogenous antioxidant enzymes in vivo. However, the significantly lower intrinsic TAC levels in PBMC from CCS patients compared with PBMC from controls pointed toward an oxidant-antioxidant imbalance in patients, highlighting the possible impact of exogenous environmental factors, such as sedentary lifestyle and unhealthy diet. The TAC assay is a copper-based assay which measures a large range of lipophilic or thiol-based antioxidants and antioxidant macromolecules but not the antioxidant enzymes discussed above [31, 32]. As a further evidence of oxidant-antioxidant imbalance, we found that the oxLDL/LDL ratios were significantly higher in the patient group indicating a higher degree of oxdation in their LDL particles. Therefore, given the high susceptibility of $\mathrm{T}_{\text {reg }}$ cells to oxidative stress, it is reasonable to assume that the numbers of $\mathrm{T}_{\text {reg }}$ cells may be affected by the prooxidant state in CCS patients.

Interestingly, our results indicate that $\mathrm{T}_{\text {conv }}$ cells from CCS patients were affected to a greater extent by oxidative stress than $T_{\text {conv }}$ cells from controls. $T_{\text {conv }}$ cells from CCS patients were more prone to undergo cell death when treated with $\mathrm{H}_{2} \mathrm{O}_{2}$ or STS and they also expressed significantly higher levels of TrxR1. It is well documented that the proatherogenic $\mathrm{T}$ cell response in atherosclerotic lesions is reflected in peripheral blood [8]. In ACS patients, systemic T cell activation is associated with plaque instability and thrombus formation but there is also consistent evidence that the $\mathrm{T}$ cell activation persists after clinical stabilization [8-10]. T cell activation is accompanied by the release of ROS which in turn leads to an upregulation of endogenous antioxidants [33]. Moreover, the induction of Trx and TrxR1 in $\mathrm{T}$ cells upon activation was recently suggested to be a critical pathway controlling $\mathrm{T}$ cell activation and expansion [34]. We believe that the increased susceptibility to oxidative stress in $T_{\text {conv }}$ cells from patients reflects a CD4 ${ }^{+} \mathrm{T}$ cell activation that remains in CCS patients despite clinical stability and medical treatment.

A couple of limitations should be considered in this pilot study. One limitation is the limited number of patients and controls per experimental set-up, permitting only cautious conclusions about differences between the two groups. The yield levels of $T_{\text {reg }}$ cells in the subjects, particularly in the CCS patients, were not high enough to allow ex vivo experiments and gene expression analyses to be carried out in the same individuals, nor to perform functional assays. Gene expression analyses were therefore performed in a separate group of subjects, 10 patients and 10 controls, though with similar characteristics as the other subjects. Another potential limitation is that the ex vivo model, where isolated fractions of $\mathrm{T}$ cell subsets are exposed to increasing doses of $\mathrm{H}_{2} \mathrm{O}_{2}$ for a relatively short period of time, may not reflect chronic inflammation.

\section{Conclusion}

$\mathrm{T}_{\text {reg }}$ cells were highly susceptible to oxidative stress and cell death ex vivo. $\mathrm{T}_{\text {reg }}$ cells also expressed and secreted high levels of antioxidants indicating a high endogenous capacity to counteract oxidative stress in both CCS patients and controls. Given the presence of oxidant-antioxidant imbalance in the patient group, we postulate that oxidative stress may be a contributor to the $\mathrm{T}_{\text {reg }}$ cell deficit in vivo.

\section{Supplementary Information}

The online version contains supplementary material available at https://doi. org/10.1186/s12967-021-02906-2.

\section{Additional file 1: Figure S1. Representative flow cytometry images of $\mathrm{T}_{\text {reg }}$ cells defined as $\mathrm{CD} 4^{+} \mathrm{CD} 127^{\text {low }} \mathrm{CD} 25^{+}(\mathrm{A})$ and $\mathrm{T}_{\text {conv }}$ cells defined as $\mathrm{CD} 4^{+} \mathrm{CD} 127^{+} \mathrm{CD} 25^{-} \mathrm{T}$ cells (B) sorted with the EasySep Human $\mathrm{CD} 4^{+} \mathrm{CD} 127^{\text {low }} \mathrm{CD} 25^{+}$Regulatory $T$ Cell Isolation Kit. Characteristics shown are from left to right: forward and side scatter, $C D 4^{+}$signal, $C D 25^{+}$signal, and $\mathrm{CD}_{12} 7^{+}$signal. The expression of Foxp3 in $\mathrm{T}_{\text {reg }}$ and $\mathrm{T}_{\text {conv }}$ cells sorted with the EasySep Human $\mathrm{CD} 4^{+} \mathrm{CD} 127^{\text {low }} \mathrm{CD} 25^{+}$Regulatory T Cell Isolation Kit is shown in Figure $C$.}

Additional file 2: Figure S2. Representative images for assessing sensitivity to ROS-induced cell death. The results from isolated $\mathrm{T}_{\text {reg }}$ and $\mathrm{T}_{\text {conv }}$ cells are shown from the left to the right; untreated, treated with $10 \mu \mathrm{M} \mathrm{H}_{2} \mathrm{O}_{2}$ or treated with $30 \mu \mathrm{M} \mathrm{H}_{2} \mathrm{O}_{2}$. Annexin $\mathrm{V}$ and SYTOX signals are shown on the $x$ and $y$ axis, respectively. Regions include double-negative $\left(S^{--}\right)$, Annexin $\checkmark$ positive $\left(\mathrm{S}^{+-}\right)$, SYTOX positive $\left(\mathrm{S}^{-+}\right)$, and double-positive $\left(\mathrm{S}^{++}\right)$. Since it is difficult to completely separate the transition from apoptosis to necrosis with this method, cells negative for both Annexin- $V$ and SYTOX were considered viable.

Additional file 3: Figure S3. The amount of oxidative stress, measured as mean fluorescence intensity (MFI) of CellROX Green, in (A) $\mathrm{T}_{\text {reg }}$ cells from CCS patients and controls and (B) $\mathrm{T}_{\text {conv }}$ cells from CCS patients and controls following treatment with $0,10,30,60$ or $120 \mu \mathrm{M} \mathrm{H}_{2} \mathrm{O}_{2}$ for $2 \mathrm{~h}$. 


\section{Acknowledgements}

We would like to thank Mona Börjesson for her assistance in data collection. We are also especially grateful to all study participants for their willingness to participate in this study.

\section{Authors' contributions}

AKL: Methodology, data analysis, data curation, project administration, writing — review and editing. RC: Methodology, data analysis, writing — review and editing. LZ: Methodology, data analysis. GF: Methodology, data analysis. $\mathrm{LJ}$ : Data analysis, writing —original draft, writing — review and editing, project administration, funding acquisition. All authors read and approved the final manuscript.

\section{Funding}

Open access funding provided by Linköping University. This study was financially supported by Heart-Lung Foundation, Sweden (20180436), Swedish Research Council (2018-03232), and Swedish Grandlodge of Freemasonry (20191209-141318).

\section{Availability of data and materials}

All datasets used and analyzed throughout the study are available from the corresponding author based on sensible request.

\section{Declarations}

\section{Ethics approval and consent to participate}

The study was conducted in accordance with the ethical guidelines of the Declaration of Helsinki, and the research protocol was approved by the Ethical Review Board of Linköping, Sweden (M242-08). Written informed consent was obtained from all study participants.

\section{Consent for publication}

Not applicable.

\section{Competing interests}

The authors declare that they have no competing interests.

\section{Author details}

${ }^{1}$ Department of Health, Medicine and Caring Sciences, Unit of Cardiovascular Medicine, Linköping University, Linköping, Sweden. ${ }^{2}$ Department of Cardiology in Linköping, and Department of Health, Medicine and Caring Sciences, Unit of Cardiovascular Medicine, Linköping University, Linköping, Sweden. ${ }^{3}$ Department of Cardiology, Linköping University Hospital, 58185 Linköping, Sweden.

Received: 13 November 2020 Accepted: 24 May 2021

Published online: 03 June 2021

\section{References}

1. Jones DP. Redefining oxidative stress. Antioxid Redox Signal. 2006:8:1865-79.

2. Kattoor AJ, Pothineni NVK, Palagiri D, Mehta JL. Oxidative stress in atherosclerosis. Curr Atheroscler Rep. 2017;19:42.

3. Madamanchi NR, Vendrov A, Runge MS. Oxidative stress and vascular disease. Arterioscler Thromb Vasc Biol. 2005:25:29-38.

4. Ho E, Karimi Galougahi K, Liu CC, Bhindi R, Figtree GA. Biological markers of oxidative stress: applications to cardiovascular research and practice. Redox Biol. 2013;1:483-91.

5. Patel RS, Ghasemzadeh N, Eapen DJ, Sher S, Arshad S, Ko YA, Veledar E, Samady H, Zafari AM, Sperling L, et al. Novel biomarker of oxidative stress is associated with risk of death in patients with coronary artery disease. Circulation. 2016:133:361-9.

6. Gisterå A, Hansson GK. The immunology of atherosclerosis. Nat Rev Nephrol. 2017;13:368-80

7. Yarosz EL, Chang $\mathrm{CH}$. The role of reactive oxygen species in regulating T cell-mediated immunity and disease. Immune Netw. 2018;18:e14.
8. Ammirati E, Moroni F, Magnoni M, Camici PG. The role of T and B cells in human atherosclerosis and atherothrombosis. Clin Exp Immunol. 2015:179:173-87.

9. Hasib L, Lundberg AK, Zachrisson H, Ernerudh J, Jonasson L. Functional and homeostatic defects of regulatory $T$ cells in patients with coronary artery disease. J Intern Med. 2016;279:63-77.

10. Lundberg AK, Jonasson L, Hansson GK, Mailer RKW. Activation-induced FOXP3 isoform profile in peripheral CD4+ T cells is associated with coronary artery disease. Atherosclerosis. 2017;267:27-33.

11. Sakaguchi S, Sakaguchi N, Asano M, Itoh M, Toda M. Immunologic selftolerance maintained by activated $T$ cells expressing $\mathrm{IL}-2$ receptor alphachains (CD25). Breakdown of a single mechanism of self-tolerance causes various autoimmune diseases. J Immunol. 1995;155:1151-64.

12. Grant CR, Liberal R, Mieli-Vergani G, Vergani D, Longhi MS. Regulatory T-cells in autoimmune diseases: challenges, controversies and-yet-unanswered questions. Autoimmun Rev. 2015;14:105-16.

13. John K, Hardtke-Wolenski M, Jaeckel E, Manns MP, Schulze-Osthoff K, Bantel $\mathrm{H}$. Increased apoptosis of regulatory T cells in patients with active autoimmune hepatitis. Cell Death Dis. 2017:8:3219.

14. Veltkamp C, Anstaett M, Wahl K, Möller S, Gangl S, Bachmann O, HardtkeWolenski M, Länger F, Stremmel W, Manns MP, et al. Apoptosis of regulatory T lymphocytes is increased in chronic inflammatory bowel disease and reversed by anti-TNFa treatment. Gut. 2011;60:1345-53.

15. Emoto T, Sasaki N, Yamashita T, Kasahara K, Yodoi K, Sasaki Y, Matsumoto T, Mizoguchi T, Hirata K. Regulatory/effector T-cell ratio is reduced in coronary artery disease. Circ J. 2014;78:2935-41.

16. Mor A, Luboshits G, Planer D, Keren G, George J. Altered status of CD4(+) $\mathrm{CD} 25(+)$ regulatory $T$ cells in patients with acute coronary syndromes. Eur Heart J. 2006;27:2530-7.

17. Zhang WC, Wang J, Shu YW, Tang TT, Zhu ZF, Xia N, Nie SF, Liu J, Zhou SF, Li JJ, et al. Impaired thymic export and increased apoptosis account for regulatory $T$ cell defects in patients with non-ST segment elevation acute coronary syndrome. J Biol Chem. 2012;287:34157-66.

18. Albany CJ, Trevelin SC, Giganti G, Lombardi G, Scottà C. Getting to the heart of the matter: the role of regulatory T-cells (Tregs) in cardiovascular disease (CVD) and atherosclerosis. Front Immunol. 2019;10:2795.

19. Mougiakakos D, Johansson CC, Kiessling R. Naturally occurring regulatory T cells show reduced sensitivity toward oxidative stress-induced cell death. Blood. 2009;113:3542-5.

20. Jönsson S, Lundberg AK, Jonasson L. Overexpression of MMP-9 and its inhibitors in blood mononuclear cells after myocardial infarction-is it associated with depressive symptomatology? PLoS ONE. 2014;9:e105572.

21. Mougiakakos D, Johansson CC, Jitschin R, Böttcher M, Kiessling R. Increased thioredoxin-1 production in human naturally occurring regulatory $T$ cells confers enhanced tolerance to oxidative stress. Blood. 2011;117:857-61

22. Holvoet P, Vanhaecke J, Janssens S, Van de Werf F, Collen D. Oxidized LDL and malondialdehyde-modified LDL in patients with acute coronary syndromes and stable coronary artery disease. Circulation. 1998;98:1487-94.

23. Itabe H. Oxidized low-density lipoprotein as a biomarker of in vivo oxidative stress: from atherosclerosis to periodontitis. J Clin Biochem Nutr. 2012;51:1-8.

24. Li W, Lidebjer C, Yuan XM, Szymanowski A, Backteman K, Ernerudh J, Leanderson P, Nilsson L, Swahn E, Jonasson L. NK cell apoptosis in coronary artery disease: relation to oxidative stress. Atherosclerosis. 2008;199:65-72.

25. Xie L, Pandey R, Xu B, Tsaprailis G, Chen QM. Genomic and proteomic profiling of oxidative stress response in human diploid fibroblasts. Biogerontology. 2009;10:125-51.

26. Taams LS, Smith J, Rustin MH, Salmon M, Poulter LW, Akbar AN. Human anergic/suppressive CD4(+)CD25(+) T cells: a highly differentiated and apoptosis-prone population. Eur J Immunol. 2001;31:1122-31.

27. Vukmanovic-Stejic M, Zhang Y, Cook JE, Fletcher JM, McQuaid A, Masters JE, Rustin MH, Taams LS, Beverley PC, Macallan DC, Akbar AN. Human CD4+ CD25hi Foxp3+ regulatory T cells are derived by rapid turnover of memory populations in vivo. J Clin Invest. 2006;116:2423-33.

28. Plaza-Sirvent C, Schuster M, Neumann Y, Heise U, Pils MC, Schulze-Osthoff K, Schmitz I. c-FLIP expression in Foxp3-expressing cells is essential for survival of regulatory $T$ cells and prevention of autoimmunity. Cell Rep. 2017;18:12-22. 
29. Zhang X, Zhang S, Liu X, Wang Y, Chang J, Zhang X, Mackintosh SG, Tackett $\mathrm{AJ}, \mathrm{He}$ Y, Lv D, et al. Oxidation resistance 1 is a novel senolytic target. Aging Cell. 2018;17:e12780.

30. Söderberg A, Sahaf B, Rosén A. Thioredoxin reductase, a redox-active selenoprotein, is secreted by normal and neoplastic cells: presence in human plasma. Cancer Res. 2000;60:2281-9.

31. Apak R, Güçlü K, Ozyürek M, Karademir SE, Altun M. Total antioxidant capacity assay of human serum using copper(II)-neocuproine as chromogenic oxidant: the CUPRAC method. Free Radic Res. 2005:39:949-61.

32. Rubio CP, Hernández-Ruiz J, Martinez-Subiela S, Tvarijonaviciute A, Ceron JJ. Spectrophotometric assays for total antioxidant capacity (TAC) in dog serum: an update. BMC Vet Res. 2016;12:166.
33. Belikov AV, Schraven B, Simeoni L. T cells and reactive oxygen species. J Biomed Sci. 2015;22:85.

34. Muri J, Heer S, Matsushita M, Pohlmeier L, Tortola L, Fuhrer T, Conrad M, Zamboni N, Kisielow J, Kopf M. The thioredoxin-1 system is essential for fueling DNA synthesis during T-cell metabolic reprogramming and proliferation. Nat Commun. 1851;2018:9.

\section{Publisher's Note}

Springer Nature remains neutral with regard to jurisdictional claims in published maps and institutional affiliations.
Ready to submit your research? Choose BMC and benefit from:

- fast, convenient online submission

- thorough peer review by experienced researchers in your field

- rapid publication on acceptance

- support for research data, including large and complex data types

- gold Open Access which fosters wider collaboration and increased citations

- maximum visibility for your research: over 100M website views per year

At BMC, research is always in progress.

Learn more biomedcentral.com/submissions 